\title{
First record and DNA barcodes of the aquarium shrimp, Neocaridina davidi, in Central Europe from thermally polluted River Oder canal, Poland
}

\author{
Aleksandra Jabłońska ${ }^{1, *}$, Tomasz Mamos ${ }^{1}$, Piotr Gruszka ${ }^{2}$, Agnieszka Szlauer-Łukaszewska ${ }^{3}$ and \\ Michał Grabowski ${ }^{1}$ \\ ${ }^{1}$ Laboratory of Biogeography and Invertebrate Ecology, Department of Invertebrate Zoology \& Hydrobiology, Faculty of Biology \\ and Environmental Protection, University of Lodz, Banacha 12/16, 90-237 Łódź, Poland \\ ${ }^{2}$ Department of Aquatic Ecology, Maritime Institute in Gdańsk, Długi Targ 41/42, 80-830 Gdańsk, Poland \\ ${ }^{3}$ Institute for Research on Biodiversity, Department of Invertebrate Zoology and Limnology, University of Szczecin, Wąska 13, \\ 71-415 Szczecin, Poland
}

\begin{abstract}
Neocaridina davidi (Bouvier, 1904) is an exotic freshwater shrimp originating from Asia and often kept as a pet in amateur aquarium cultures. Herewith, we report on the second finding of $N$. davidi in fresh waters of Europe and the first discovery of that species both in Poland and in Central Europe. The species was found in samples collected in 2003, 2013 and 2017 in the thermally polluted canal connected to the River Oder, south of Gryfino, in the vicinity of the Dolna Odra Power Plant. The taxonomic identity of the collected shrimp was confirmed by the standard DNA barcoding procedure, using a $610 \mathrm{bp}$-long fragment of cytochrome oxidase I (COI). The findings spanning more than a decade suggest that $N$. davidi may have established a self-reproducing population at this site. Following the finding of Atyaephyra desmarestii (Millet, 1831) in 2000, Neocaridina davidi is the second freshwater shrimp species found in the River Oder and in Poland.
\end{abstract}

Keywords: Atyidae / freshwater shrimp / alien species / DNA barcoding / thermal pollution

Résumé - Premier signalement et code-barres ADN de la crevette d'aquarium, Neocaridina davidi, en Europe centrale dans le canal de l'Oder pollué thermiquement, Pologne. Néocaridina davidi (Bouvier, 1904) est une crevette exotique d'eau douce originaire d'Asie et souvent conservée dans des aquariums amateurs. Ici, nous présentons le deuxième signalement de $N$. davidi dans les eaux douces d'Europe et la première découverte de cette espèce en Pologne et en Europe centrale. L'espèce a été trouvée dans des échantillons prélevés en 2003, 2013 et 2017 dans le canal thermiquement pollué relié à l'Oder, au sud de Gryfino, à proximité de la centrale électrique de Dolna Odra. L'identité taxonomique des crevettes collectées a été confirmée par la procédure standard de code-barres ADN, utilisant un fragment de cytochrome oxydase I (COI) de $610 \mathrm{pb}$ de longueur. Les résultats sur plus d'une décennie suggèrent que $N$. davidi a peut-être établi une population autoreproductrice sur ce site. Après la découverte d'Atyaephyra desmarestii (Millet, 1831) en 2000, Neocaridina davidi est la deuxième espèce de crevettes d'eau douce trouvée dans l'Oder et en Pologne.

Mots clés : Atyidae / crevette d'eau douce / espèce exotique / code-barres ADN / pollution thermique

Human-mediated introductions of alien species into fresh waters is a well-known phenomenon world-wide. Tropical and subtropical organisms are able to inhabit thermally polluted water bodies of the temperate zone (Maczulak, 2010). In Europe, classic examples of alien invertebrates thriving in

\footnotetext{
*Corresponding author:

aleksandra.jablonska@biol.uni.lodz.pl
}

water bodies with elevated water temperatures include Branchiura sowerbyi (Oligochaeta) and Sinanodonta woodiana (Bivalvia), both originating from tropical and subtropical Asia (Gruszka, 1999, Kraszewski and Zdanowski, 2011, Jabłońska et al., 2015).

The shrimp Neocaridina davidi (Bouvier, 1904) occurs naturally in fresh waters of South-East Asia (Cai 1996). It has already been introduced to Hawaii (Englund and Cai, 1999) 
Table 1. Sequences used in analysis.

\begin{tabular}{llll}
\hline Accession number & Species & Locality & Reference \\
\hline AB300183 & Neocaridina davidi & Taiwan (Taichung County) & Shih \& Cai 2007 \\
AB300184 & Neocaridina davidi & Taiwan (Yunlin County) & Shih \& Cai 2007 \\
AB300185 & Neocaridina davidi & Hawaii (Oahu) & Shih \& Cai 2007 \\
AB300186 & Neocaridina davidi & Hawaii (Oahu) & Shih \& Cai 2007 \\
AB300187 & Neocaridina davidi & Taiwan (Kinmen County) & Shih \& Cai 2007 \\
AB300190 & Caridina cantonensis & China (Guangdong Province) & Shih \& Cai 2007 \\
MG816764 & Neocaridina davidi & Poland (Oder River) & This study \\
MG816766 & Neocaridina davidi & Poland (Oder River) & This study \\
MG816769 & Neocaridina davidi & Poland (Oder River) & This study \\
MG816771 & Neocaridina davidi & Poland (Oder River) & This study \\
MG816772 & Neocaridina davidi & Poland (Oder River) & This study \\
MG816774 & Neocaridina davidi & Poland (Oder River) & This study \\
MG816775 & Neocaridina davidi & Poland (Oder River) & This study \\
MG816765 & Neocaridina davidi & Poland (aquarium collection) & This study \\
MG816767 & Neocaridina davidi & Poland (aquarium collection) & This study \\
MG816768 & Neocaridina davidi & Poland (aquarium collection) & This study \\
MG816770 & Neocaridina davidi & Poland (aquarium collection) & This study \\
MG816773 & Neocaridina davidi & Poland (aquarium collection) & This study \\
MG816776 & Neocaridina davidi & & This study \\
\hline
\end{tabular}

and Japan (Nishino and Niwa, 2004). In Europe, this species is an extremely popular aquarium pet (Nur and Christianus, 2013, Horwath, 2015, Pantaleão et al., 2017) but was only recently found in nature, in thermally polluted tributaries of the River Rhine, Western Europe (Klotz et al., 2013).

In this study, we provide a first report on the occurrence of $N$. davidi in Poland, Central Europe. The shrimp were collected in a ca. $4.5 \mathrm{~km}$-long artificial canal connected to the lower section of the Oder River, south of Gryfino $\left(\mathrm{N} 53^{\circ} 12^{\prime} 42.36^{\prime \prime}, \mathrm{E} 14^{\circ} 28^{\prime} 2.70^{\prime \prime}\right)$. The canal receives heated waters from the large Dolna Odra Power Station cooling system. Bottom sediments at the sampling site were composed of fine-grained sands and mud. The banks were partially covered by concrete. The water temperature at the sampling site in June - July was $27-29^{\circ} \mathrm{C}$, while in November, it dropped to $15^{\circ} \mathrm{C}$. A total of 15 animals were found in qualitative benthic samples, collected using a hydrobiological hand-net from submerged vegetation in July 2003 (3 individuals), November 2013 (3 ind.) and June 2017 (9 ind.). The sample from June 2017, was taken from a $1 \mathrm{~m}^{2}$ surface in about $15 \mathrm{~min}$ sampling time. For comparison and taxonomic verification, in 2017, we acquired six specimens of $N$. davidi var. "Red Cherry" from an amateur aquarium culture in Łódź, Poland, ca. $500 \mathrm{~km}$ south-east from the sampling site. All individuals, except the sample from 2003 (which was preserved in $4 \%$ formaldehyde), were instantly preserved in $96 \%$ ethanol.

Morphological examination of shrimp was carried out using descriptions in papers by Englund and Cai (1999) and Klotz et al. (2013). Individuals were then DNA-barcoded using the cytochrome $c$ oxidase subunit I (COI) marker. Total DNA was extracted from the abdominal tissue of 13 specimens, collected both from the field and from aquarium using the Chelex procedure (Casquet et al., 2012). The PCR reaction followed the protocol provided by Hou et al. (2007), with the primer pair HCOJJ/LCOJJ (Astrin and Stüben, 2008).
PCR products were purified with Exonuclease I and FastAP alkaline phosphatase (Werle et al., 1994), and then sequenced by Macrogen Inc., Korea. The obtained sequences are deposited in GenBank (Benson et al., 2005). The GenBank accession numbers are provided in Table 1 . In addition, we acquired five COI sequences of Neocaridina davidi from Taiwan and Hawaii, published and deposited in GenBank, under the name Neocaridina denticulata sinensis (Kemp, 1918), by Shih and Cai (2007) (Tab. 1). The sequences were aligned and trimmed to the length of $610 \mathrm{bp}$ in Geneious 6.1.8 (Kearse et al., 2012). Haplotypes were identified using the DnaSP software (Librado and Rozas, 2009). The Neighbour-Joining method was applied using Mega 7.0 (Kumar et al., 2016). Caridina cantonensis COI sequence was chosen as an outgroup (Tab. 1).

The material examined morphologically, contained five males and 16 females (one ovigerous, collected in November 2013). All individuals were identified morphologically as Neocaridina davidi using the following characteristics (based on all the individuals found at the sampling site). Body length, 13 to $24.5 \mathrm{~mm}$. Average body length of males: $15.5 \mathrm{~mm}$, average body length of females: $19.3 \mathrm{~mm}$. Rostrum, with 1318 dorsal teeth (2-4 postorbital) and 4-8 ventral teeth, reaching the distal edge of the third antennular segment. The tip of the rostrum slender, slightly curved, without teeth. Eyes, normally developed. Carapace smooth. Supraorbital spine absent. Antennal spine well-developed. Pterygostomian angle acute and sharply pointed. Pereiopods normally developed, characteristic of the family Atyidae. Spines on dactylus of the 3rd pair of pereiopods in males stronger and thicker than in females. Endopod of the 1st male pleopod, pear-shaped, broad and rounded in its distal part. Telson, shorter than uropods, with 4-5 pairs of dorsal spines, margin rounded, armed with 810 long spines.

DNA COI barcodes also confirmed that all the studied shrimps belong to Neocaridina davidi. The haplotype assignment showed that all the individuals, collected either 


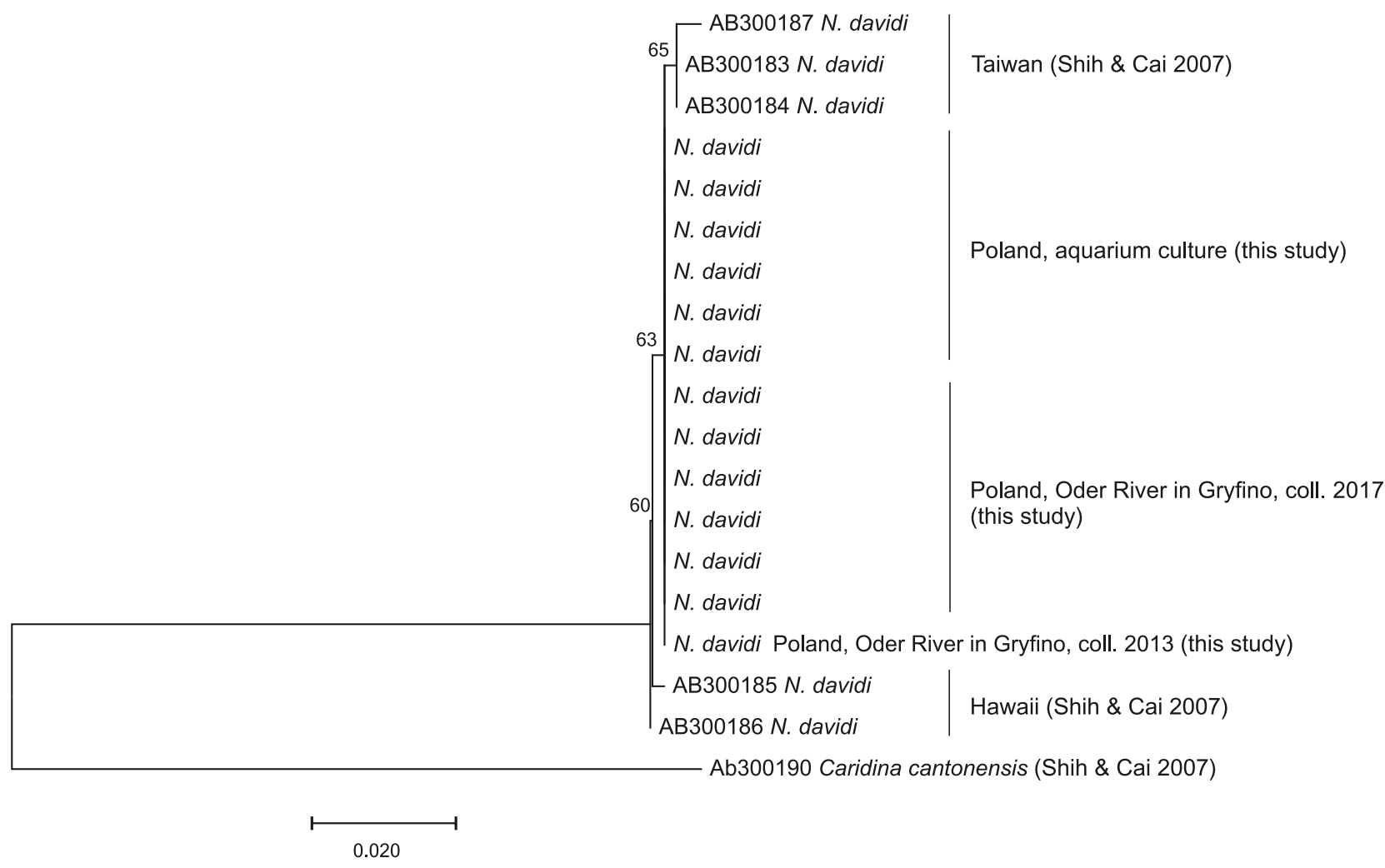

Fig. 1. Neighbour-Joining tree constructed for newly obtained and GenBank-stored sequences of Neocaridina davidi.

in the wild or from the aquarium culture, belonged to a single haplotype (Fig. 1). Moreover, four other COI haplotypes of individuals from Hawaii and Taiwan, acquired from GenBank, differed from the sequences we obtained, by only one to three mutations.

The results of our morphological and genetic analyses confirms the presence of $N$. davidi in the thermally-polluted canal connected to River Oder near Gryfino, Poland. Low numbers of shrimp found in the samples may indicate low abundance and density. The population in the sampling site is distributed pointwise and it is probable that numerous suitable habitats are inaccessible for sampling, enclosed in the Power Plant's grounds. This is the second record of this species, from European surface waters and the first from Central Europe. Neocaridina davidi is the second freshwater shrimp species reported from Poland after Atyaephyra desmarestii recorded previously from the western, natural, branch of the Oder River near Gryfino (Gruszka, 2001). Although both shrimps, $N$. davidi and A. desmarestii, belong to family Atyidae, the differences in their morphology are clear (Klotz et al., 2013).

Neocaridina davidi, particularly the variety "Red Cherry", is a very popular aquarium pet world-wide, including Europe (Nur and Christianus, 2013, Horwath, 2015, Pantaleão et al., 2017). We propose that, as in the Rhine tributaries in western Germany, the population occurring in the canal near Gryfino derives from an aquarium culture, especially since the wild individuals share the same haplotype as the cultured ones. Moreover we cannot exclude the possibility that the population has been settled in this place for more than a decade. The individuals (including one ovigerous female) were collected in 2003, 2013 and 2017, the temperature in the canal reaches $27-28^{\circ} \mathrm{C}$, which are the most favorable values for breeding of $N$. davidi (Nur and Christianus, 2013, Tropea et al., 2015). Another possibility, although less probable over such a long period, would be a series of yearly introductions supplying the population regularly with captive-bred individuals. Thus, the population should be investigated in the coming years to check its stability at the study site. It would be also interesting to study a wider area to ascertain if the species is spreading.

Although releasing aquarium pets into open waters can be harmful for natural ecosystems, this phenomenon is quite common (Gherardi et al., 2007, Lipták and Vitázková, 2015). Aquarists often believe this is a more humanitarian solution than killing unwanted pets (Duggan, 2011). In some cases, stable populations of exotic species pose a threat to native species and entire ecosystems including increased predatory pressure on indigenous fauna or introduction of new diseases or pathogens (Gherardi et al., 2007, Klotz et al., 2013, Weber and Traunspurger, 2016). So far, no such threats associated with $N$. davidi have been found in nature. On the other hand, most tropical organisms introduced to natural waters in temperate climates are not able to survive the winter. Some, however, do find the new conditions advantageous. Klotz et al. (2013) noted that the native habitat of $N$. davidi is not tropical, since the water temperatures range from $6{ }^{\circ} \mathrm{C}$ in winter to $30^{\circ} \mathrm{C}$ in summer. Such winter temperatures are still $2-4^{\circ} \mathrm{C}$ higher than those in Central Europe (Wetzel, 2001). Nevertheless, the global warming associated with prolonged periods without cold spells in winters and heat waves in summers (Anders et al., 2014), makes the temperate zones more prone for acclimatization of thermophilic species. Such is the case of the predominantly Mediterranean scarlet dragonfly, Crocothemis 
erythraea (Brullé, 1832), recently expanding its breeding range in Central Europe (Ott, 2010). We suppose that thermally polluted water bodies may serve as gateway ecosystems in which such species adapt to local conditions and, in the future, colonize natural waters. After acclimatization, the further spread of alien freshwater species is usually promoted by other human activities, such as building artificial channels connecting previously isolated river basins, inland waterway transportation, tourist movement as well as by ecosystems degradation (Gherardi, 2007). Thus, we suspect that, with increasing propagule pressure from amateur aquarists, further climate warming and connection of inland waterways, $N$. davidi will likely spread in Central Europe and become a stable element of local fauna, as the thermophilic Procambarus clarki (Girard, 1852) has in many other regions of Europe (SoutyGrosset et al., 2016). It would be beneficial to promote the education and awareness of the problems of releasing nonnative aquarium species into water systems. This activity is an adverse procedure for natural environments, particularly because controlling such activities is very difficult.

Acknowledgements. The study was supported by the internal funds of the University of Lodz. We would like to thank Andrzej Zawal (University of Szczecin) and Jacek Sadowski (West Pomeranian University of Technology Szczecin) for providing some material used in this study. Finally, we would like to thank dr. Tammy Horton, National Oceanography Center, Southampton, UK, for the language corrections.

\section{References}

Anders I., Stagl J., Auer I., Pavlik D. Climate change in central and eastern Europe. In: Rannow S., Neubert M. ed. Managing protected areas in central and eastern Europe under climate change. Springer Science+Business, Dodrecht, 2014, pp 17-30.

Astrin J.J., Stuben P.E. 2008. Phylogeny in cryptic weevils: molecules, morphology and new genera of western Palaearctic Cryptorhynchinae (Coleoptera: Curculionidae). Invertebr Syst 22: 503-522.

Benson D.A., Karsch-Mizrachi I., Lipman D.J., Ostell J., Wheeler D.L. 2005. GenBank. Nucleic Acids Res 33: D34-D38. DOI:10.1093/nar/gki063

Bouvier M.E.-L. 1904. Crevettes de la famille des Atyidés: espèces qui font partie des collections du Muséum d'Historie naturelle. Bull Mus Hist Nat 10: 129-138

Brullé A. 1832. Expédition scientifique de Moreé, 3. Levrault, Paris.

Cai Y. 1996. The revision of the genus Neocaridina (Crustacea: Decapoda: Atyidae). Acta Zootaxonomica Sinica 21: 129-160

Casquet J, Thebaud C, Gillespie RG. 2012. Chelex without boiling, a rapid andeasy technique to obtain stable amplifiable DNA from small amounts of ethanol-stored spiders. Mol Ecol Resour 12: 13641. DOI:10.1111/j.1755-0998.2011.03073.x

Duggan J.C. 2011. Aquaria. In: Simberloff D., Rejmánek M. ed. Encyclopedia of biological invasions. University of California Press, Berkeley, Los Angeles, London: 32-35.

Englund R.A., Cai Y. 1999. The occurrence and description of Neocaridina denticulata sinensis (Kemp, 1918) (Crustacea: Decapoda: Atyidae), a new introduction to the Hawaiian Islands. Bishop Mus Occas Pap 58: 58-65.

Gherardi F. Biological invasions in inland waters: an overview. In: Gherardi F. ed. Biological invaders in inland waters: profiles, distribution and threats. Invading Nature - Springer series in invasion ecology. Vol. 2. Springer, Dordrecht, 2007, 3-25.

Gherardi F., Gollasch S., Minchin D., Olenin S., Panov V.E. Alien invertebrates and fish in European inland waters. In: Gherardi F. (Ed.) Biological invaders in inland waters: profiles, distribution and threats. Invading Nature - Springer series in invasion ecology. Vol. 2. Springer, Dordrecht, 2007, 81-92.

Girard C.F. 1852. A Revision of the North American Astaci, with Observations on Their Habits and Geographic Distribution. Proc Acad Nat Sci Phila. 6: 87-91.

Gruszka P. 1999. The River Odra estuary as a gateway for alien species immigration to the Baltic Sea Basin. Acta Hydroch Hydrob 27: $374-382$.

Gruszka P. 2001. Atyaephyra desmaresti (Millet, 1831) (Crustacea: Decapoda)-nowy dla fauny Polski gatunek w rzece Odrze, In: Sesja naukowa z okazji jubileuszu 50-lecia Wydziału Rybactwa Morskiego i Technologii zywnosci, 28-29 czerwiec 2001, Akademia Rolnicza w Szczecinie, Szczecin 2001, 31

Horwath G. 2015. First bite of the cherry. Practical Fishkeeping 3, $72-78$.

Hou Z., Fu J., Li S., 2007. A molecular phylogeny of the genus Gammarus (Crustacea: Amphipoda) based on mitochondrial and nuclear gene sequences. Mol Phylogenet Evol 2: 596-611. DOI:10.1016/j.ympev.2007.06.006

Jabłońska A., Szlauer-Łukaszewska A., Bańkowska A. 2015. Aulodrilus pigueti Kowalewski, 1914 (Annelida: Clitellata) - a new record for the Polish fauna from the Oder River and remarks on other oligochaetes rarely noticed in Poland. Oceanol Hydrobiol Stud 44: 456-465.

Kearse M., Moir R., Wilson A., et al., 2012. Geneious Basic: An integrated and extendable desktop software platform for the organization and analysis of sequence data. Bioinformatics 28: 1647-1649. DOI:10.1093/bioinformatics/bts199

Kemp S. 1918. Zoological results of a tour in the Far East. Crustacea Decapoda and Stomatopoda. Mem Asiatic Soc Bengal 6: 218-297.

Klotz W., Miesen F.W., Hüllen S., Herder F. 2013. Two Asian fresh water shrimp species found in a thermally polluted stream system in North Rhine-Westphalia, Germany. Aquat Invasions 8: 333-339. DOI:10.3391/ai.2013.8.3.09

Kraszewski A., Zdanowski B. Sinanodonta woodiana (Lea, 1834). In: Głowacinski Z., Okarma H., Pawłowski J., Solarz W. ed. Alien Species in the fauna of Poland. Institute of Environmental Protection, Polish Academy of Sciences, Krakow, 2011

Kumar S., Stecher G., Tamura K. 2016. MEGA 7: Molecular Evolutionary Genetics Analysis version 7.0 for bigger datasets. Mol Biol Evol 33: 1870-1874. DOI:10.1093/molbev/msw054

Librado P., Rozas J., 2009. DnaSP v5: a software for comprehensive analysis of DNA polymorphism data. Bioinformatics 25, 14511452. DOI:10.1093/bioinformatics/btp187

Lipták B., Vitázková B. 2015. Beautiful, but also potentially invasive. Ekológia (Bratislava) 34: 155-162. DOI:10.1515/eko-2015-0016

Maczulak A. 2010. Pollution: treating environmental toxins. Facts on file. Infobase Publishing, New York.

Millet P.A. 1831. Description d'une nouvelle espèce de crustacé, l'Hippolyte de Desmarets. Mém Soc Agr sci et arts d'Angers 1: $55-57$.

Nishino M., Niwa N. 2004. Invasion of an alien freshwater shrimp Neocaridina denticulata sinensis to lake Biwa. Lake Biwa Res Inst News 80: 3.

Nur F.A.H., Christianus A. 2013. Breeding and life cycle of Neocaridina denticulate sinensis (Kemp, 1918). Asian J Animal Vet Adv 8: 108-115. 
Ott J., 2010. Dragonflies and climatic change - recent trends in Germany and Europe. BioRisk 5: 253-286. DOI:10.3897/bio risk.5.857

Pantaleão J.A.F., Gregati R.A., Da Costa R.C., López-Greco L.S., Negreiros-Fransozo M.L. 2017. Post-hatching development of the ornamental "Red Cherry Shrimp" Neocaridina davidi (Bouvier, 1904) (Crustacea, Caridea, Atyidae) under laboratorial conditions. Aquac Res 48: 553-569. DOI:10.1111/are.12903

Shih H-T., Cai Y. 2007. Two new species of the land-locked freshwater shrimp genus, Neocaridina Kubo, 1938 (Decapoda: Caridea: Atyidae), from Taiwan, with notes on speciation on the island. Zool Stud 46: 680-694.

Souty-Grosset C., Anastácio P.M., Aquiloni L., et al. 2016. The red swamp crayfish Procambarus clarkii in Europe: Impacts onaquatic ecosystems and human well-being. Limnologica 58: 78-93.
Tropea C., Stumpf L., López Greco L.S. 2015. Effect of temperature on biochemical composition, growth and reproduction of the ornamental red cherry shrimp Neocaridina heteropoda heteropoda (Decapoda, Caridea). Plos ONE 10: e0119468. DOI:10.1371/ journal.pone. 0119468

Weber S., Traunspurger W. 2016. Influence of the ornamental red cherry shrimp Neocaridina davidi (Bouvier, 1904) on freshwater meiofaunal assemblages. Limnologica 59: 155-161. DOI:10.1016/ j.limno.2016.06.001

Werle E., Schneider C., Renner M., Völker M., Fiehn W., 1994. Convenient single-step, one tube purification of PCR products for direct sequencing. Nucleic Acids Res 22: 4354-4355.

Wetzel R.G. 2001. Limnology. Lake and River Ecosystems. Academic Press. San Diego, San Francisco, New York, Boston, London, Sydney, Tokyo.

Cite this article as: Jabłońska A, Mamos T, Gruszka P, Szlauer-Łukaszewska A, Grabowski M. 2018. First record and DNA barcodes of the aquarium shrimp, Neocaridina davidi, in Central Europe from thermally polluted River Oder canal, Poland. Knowl. Manag. Aquat. Ecosyst., 419, 14 